\title{
Violência e desigualdade: Reflexões sobre o problema da violência rural no Brasil contemporâneo
}

Violence and Inequality: Reflections on the Problem of Rural Violence in Present-day Brazil

Violence et inégalité: réflexions sur le problème de la violence rurale dans le Brésil contemporain

\section{Adalmir Leonidio}

\section{OpenEdition}

\section{Journals}

Edição electrónica

URL: http://journals.openedition.org/rccs/4943

DOI: $10.4000 /$ rccs. 4943

ISSN: 2182-7435

\section{Editora}

Centro de Estudos Sociais da Universidade de Coimbra

Edição impressa

Data de publição: 1 Junho 2012

Paginação: 85-106

ISSN: 0254-1106

\section{Refêrencia eletrónica}

Adalmir Leonidio, "Violência e desigualdade: Reflexões sobre o problema da violência rural no Brasil contemporâneo ", Revista Crítica de Ciências Sociais [Online], 97 | 2012, colocado online no dia 19 abril 2013, criado a 30 abril 2019. URL : http://journals.openedition.org/rccs/4943 ; DOI : 10.4000/ rccs. 4943 


\section{ADALMIR LEONIDIO}

\section{Violência e desigualdade: Reflexões sobre o problema da violência rural no Brasil contemporâneo*}

Este artigo discute, de forma resumida, os principais resultados e argumentos de uma pesquisa mais ampla sobre a violência rural contemporânea no Brasil. A análise empírica esteve focada na região no Pontal do Paranapanema, extremo oeste do estado de São Paulo, uma das mais violentas do país. Embora se trate de um estudo do tempo presente, ele teve sempre por perspectiva seus fundamentos históricos que vêm do passado. Isto é, buscou-se pensar a violência rural na região como um problema estrutural, relacionado, sobretudo, ao valor histórico das desigualdades no Brasil.

Palavras-chave: Brasil; conflitos - aspetos históricos; desigualdade; espaço rural; posse da terra; violência.

... Mesmo quando as minhas mãos estão ocupadas em torturar, esganar, trucidar Meu coração fecha os olhos e sinceramente chora...

Chico Buarque de Holanda

\section{Uma breve introdução ao problema de pesquisa}

A questão que se coloca neste trabalho e que serve como hipótese investigativa é a seguinte: em que medida os enormes obstáculos encontrados no mundo da lei no Brasil têm influenciado o refluxo dos movimentos de luta pela realização da reforma agrária nos últimos anos? E em que medida estes mesmos obstáculos têm alimentado uma cultura política amplamente permeável ao uso da violência como mediação dos conflitos? Para o entendimento da questão,

\footnotetext{
* Pesquisa financiada pela FAPESP e apresentada como tese de Livre-Docência na Universidade de São Paulo.
} 
parte-se do pressuposto de que a violência no meio rural brasileiro - onde o mundo das leis custa a chegar - diferencia-se pelo caráter das relações sociais predominantes no país e pela mentalidade que a envolve, sendo marcada por profundas desigualdades, cujas raízes remontam aos tempos da escravidão e do coronelismo, ou melhor, à forma como se constituiu a nação, cindida em pedaços. Naquele tempo, estabeleceu-se um estilo de convivência social entre as classes - senhores e escravos - que deixou marcas profundas na sociedade atual, conformando cidadãos de categorias distintas e que por isso podem ser tratados pela lei de formas também distintas. Os escravos de ontem e os pobres de hoje parecem fazer parte de um "outro" nacional, diferentes dos "autênticos" cidadãos. No dizer de Angela Mendes de Almeida, "classes torturáveis", em oposição às "classes confortáveis" (Almeida, 1999).

E como tem se apresentado este problema na discussão atual sobre a violência? Recentemente tem-se discutido o problema da violência nas sociedades contemporâneas, ditas pós-modernas. Nestas sociedades, segundo Michel Wieviorka (1997), o monopólio legítimo da violência física aparece cada vez mais atomizado e as práticas violentas se disseminam como norma social particular de amplos grupos da sociedade, invertendo as expectativas do processo civilizatório descrito por Norbert Elias (1999). Fala-se ainda em uma multiplicação das formas de violência - exclusão social, violência racial, violência sexual, violência escolar, violência criminal, violência ecológica, etc. (Santos, 1999).

Os autores têm usado então a noção de "violência difusa" para referir-se a essa violência disseminada em suas múltiplas formas na sociedade (Santos, 2004). Violência que não é condenada pela sociedade e nem pela lei, mas que, em grande medida, é legitimada pela consciência coletiva. O termo "difusa" refere-se também à possibilidade de todos serem igualmente vítimas de práticas violentas, ressaltando assim um pretenso "lado democrático" da violência (Barreira, 2008).

Onde estariam as causas sociais desses "atos de violência difusa"? Em larga medida, no desemprego estrutural, nos processos de exclusão social e econômica, na fragmentação social e na crise da concepção tradicional dos direitos sociais em oferecer um quadro para pensar os excluídos. Há que fazer referência ainda ao processo de ruptura do contrato e dos laços sociais, em função não apenas da crise do Estado de bem-estar social, mas também das instituições socializadoras tradicionais, como a família, a escola, as fábricas, as religiões, etc. (Santos, 2004; Méndez, 2004).

Em suma, vendo as coisas sob esta perspectiva, o que se percebe é que a atualização da discussão da violência no Brasil tem descuidado as particularidades históricas de sua formação social. Tem-se falado da crise das instituições 
de controle da violência, como a família, o Estado, a Igreja, etc. Mas não se tem mostrado a relação destas instituições, em sua formação histórica, com o problema da violência. O Estado, que deveria zelar pela segurança dos cidadãos, tem sido, no Brasil, o primeiro a violar sistematicamente os direitos humanos, ao vitimar de forma truculenta e arbitrária as populações pobres do campo e da cidade. Por seu lado, é no seio das famílias que se têm cometido as maiorias barbaridades, quando o assunto é violência privada: o sadismo das variadas formas de tratamento do escravo no interior da casa-grande; a coerção moral e física dos agregados das grandes fazendas, nos tempos do coronelismo; a violência contra mulheres e crianças, nos dias atuais. Enfim, o que se observa, olhando em uma perspectiva de longa duração, é um movimento lento e persistente em que a violência gerada no recinto privado invade a esfera pública, estabelecendo aí suas normas desiguais.

Também se tem enfatizado no Brasil, em alguns trabalhos, a violência de classe como uma espécie de reação das elites do país às variadas formas de manifestação de insatisfação ou "desobediência" dos trabalhadores rurais. O que é preciso destacar, no entanto, é que a violência que se tem aceitado com resignação ou até naturalidade, violência de senhores contra escravos e de ricos contra pobres, além de ser uma demonstração de mando ou força, é também uma forma de indicar aos de baixo seu lugar social em uma sociedade marcada por profundo sentimento de desigualdade, uma forma de pacificação social que tem como pano de fundo aquele velho estilo de convivência herdado dos tempos da escravidão. Daí por que ninguém questionava, naqueles tempos, o tratamento cruel dispensado aos escravos, bem como tende a predominar, nos tempos de hoje, um manto de silêncio sobre as execuções sumárias de menores infratores; sobre a tortura nas prisões; sobre os maus-tratos e até assassinatos de trabalhadores em situação análoga à da escravidão; sobre o massacre de trabalhadores rurais e suas lideranças, entre outros. O sentimento comum nestes casos é de que "não são brasileiros como nós".

\section{O contexto histórico da pesquisa}

O pressuposto essencial deste trabalho é que não se entenderá plenamente o problema estrutural da violência no Brasil sem relacioná-la à instituição escravista, que grassou no país por quase quatro séculos. Tanto quanto a naturalização do valor da desigualdade no mais íntimo das pessoas, um dos traços mais conhecidos do escravismo no Brasil foi a violência que caracterizou as relações entre senhores e escravos, violência tolerada e aceita por todos, e alargada muito para além do âmbito estrito das relações de produção, penetrando toda a sociedade e fazendo-se norma socialmente aceita. Ela penetrou 
e exerceu ampla influência em vários setores da vida social. Descrevendo o tipo psicológico do senhor de engenho, Gilberto Freyre o caracterizou como de caráter "arrogante e violento" em muitas circunstâncias (Freyre, 1987).

Tanto Freyre quanto Sérgio Buarque de Holanda atribuem esta postura à posição social ocupada pelo senhor de engenho nos tempos coloniais. Conforme salientou Holanda, toda estrutura de nossa sociedade colonial teve sua base fora dos meios urbanos. Nos domínios rurais é a família patriarcal que prevalece como base e centro de toda a organização. Neles, a autoridade do proprietário de terras não sofria réplicas, seja na relação de pai para filho, de marido para mulher, de senhor para escravo ou mesmo na relação com os seus apaniguados e dependentes (Holanda, 1995). Portanto, é no ambiente privado, no "seio acolhedor" da família brasileira, que se vê gestar e nascer a violência como expressão do poder de classe, depois estendida ao domínio público.

Mas aqui entra uma outra questão de fundamental importância para se entender a naturalidade da violência no Brasil e o sentido da impunidade, que é a ambiguidade da forma como a violência se manifestava nos tempos da escravidão, violência do senhor contra o escravo, e da forma como ela se manifesta hoje, dos ricos contra os pobres. Sérgio Buarque de Holanda havia dito que a "moral das senzalas", que penetrou em amplos setores da sociedade, havia sido "sinuosa até na violência" (Holanda, 1995: 62). Estaria o autor negando a existência da violência entre senhores e escravos, como muitos argumentaram? Em nosso entender, não. Quis antes falar da presença do afetivo, do passional, do irracional, de sentimentos próprios ao núcleo familiar nas relações sociais que permeiam a sociedade brasileira. Segundo este ponto de vista, as pessoas se relacionavam umas com as outras, por sentimentos e deveres, nunca por interesses e ideias.

Esta mentalidade, tão marcante no Brasil até aos dias de hoje, está relacionada à forma como se organizou a sociedade brasileira desde os tempos coloniais, centrada na família extensa, com seus inúmeros agregados, isto é, nas relações entre famílias e facções, e não entre indivíduos livres e iguais (Holanda, 1995; Prado Jr., 1995). De acordo com o modelo de distribuição de terras predominante no Brasil Colônia, os posseiros que não haviam sido agraciados com a mercê real de uma sesmaria dependiam do favor de um poderoso fazendeiro-sesmeiro para garantir sua permanência na terra. Isto é, os direitos dos camponeses que viviam como agregados só eram reconhecidos como extensão dos direitos dos fazendeiros, como concessão destes, como questão privada e não pública. Invariavelmente, a retribuição deste "favor" significava que o agregado lutava com o fazendeiro e pelo fazendeiro. Em suma, todos deviam sua existência, sempre subserviente, 
aos poderosos patriarcas rurais. Daí o recurso simultâneo do favor e do porrete, do paternalismo e da violência no comando dessa extensa família.

Segundo Sérgio Buarque, o tipo de homem que se origina destas relações sociais familiais é o "homem cordial". Não o homem bom, pacífico e alegre por natureza, como quer o senso comum sobre o brasileiro. Mas aquele que age com o coração. E a violência que daí brota faz prevalecer seus sentimentos sobre a aplicação pública da lei. Por isso mesmo ele é também tolerante em relação à violência, desde que ela não atinja sua família e seus amigos. Lembrando o velho ditado da Primeira República, "aos amigos a justiça, aos inimigos o rigor da lei". E o "rigor da lei", na maioria das vezes, quer dizer exatamente o oposto, o arbítrio, o abuso, etc.

Este estilo de convivência vai muito além do tempo dos barões, invadindo a República e impregnando sua cultura política. Neste tempo, a força das oligarquias estaduais tinha sua base formada pelos coronéis, que controlavam ao nível do município a grande maioria da massa eleitoral do país. No meio rural, que ainda agrupava a maior parte da população e as principais atividades do país, a estrutura social continuava sendo definida pelo clássico binômio senhor de terras e seus dependentes. O patrão não é aquele que compra a força de trabalho de uma massa assalariada cuja vida pessoal não lhe interessa diretamente, mas o "benfeitor" de uma população que pode ser entendida como seus protegidos; é dele que estes recebem os únicos favores que sua miserável existência pode conhecer. Daí a lealdade que lhe retribuem: no plano político luta "com o coronel" e "pelo coronel", pois é dele que sua existência depende. $\mathrm{O}$ coronel exerce, pois, ampla jurisdição não somente sobre seus dependentes diretos, como sobre toda a vida local: é ele quem faz justiça, realiza casamentos, promove o mínimo de melhorias públicas, ajuda os necessitados e apadrinhados, exerce funções policiais e concede favores de toda ordem - desde empregos públicos até cargos políticos de prestígio o que fazia aumentar a massa de seus clientes reais e potenciais. Além disso, é dessa massa de dependentes e protegidos que o coronel recruta seus grupos de capangas, por meio dos quais impunha "sua lei", isto é, favorecendo os "amigos" e prejudicando os "inimigos" (Queirós, 1982).

Esta desigualdade na aplicação da violência, que gradativamente vai se institucionalizando, está relacionada, como dito, com aquele velho estilo de convivência entre as classes sociais no Brasil, herdado da escravidão e baseado em um profundo sentimento de desigualdade entre as pessoas. Costuma-se dizer que a "era Vargas" iniciou um processo de reversão desse sentimento através de um projeto nacional de modernização, com extensão dos direitos sociais e sobretudo com um projeto de educação pública e gratuita para todos. Hoje, contudo, percebe-se claramente que essa modernização, 
que se estendeu até o início da ditadura militar, em 1964, não salvou o país de suas mazelas coloniais e em muitos aspectos representou mesmo certo nível de continuidade. Pois, afinal, descobriu-se que o desenvolvimento econômico que the serviu de base foi feito para marginalizar, mais que para construir uma nação cimentada e solidária. Tal como nos tempos da escravidão, a nação continuava cindida em pedaços.

Durante o período da ditadura (1964-1984) há um grande crescimento do Estado policial e penal. Também aqui, como na era Vargas, os direitos civis e políticos são restringidos de forma extremamente violenta: sindicatos, jornais, universidades, entre outras organizações, têm suas sedes ocupadas e vigiadas; ao mesmo tempo, a morte e o desaparecimento de inúmeras lideranças políticas, assim como a deposição de governadores eleitos e o controle e posterior dissolução do Congresso, a cassação de direitos políticos, a tortura e a instituição da pena de morte por fuzilamento dão o tom dos anos de terror do regime militar. As torturas, execuções sumárias e outras formas de violação de direitos humanos eram práticas rotineiras no novo regime, como ademais ainda o são em relação à periferia pobre do país.

Com o processo de abertura política, a partir de 1974, voltam à cena os direitos civis e políticos cassados anteriormente. Apesar do predomínio das imensas desigualdades econômicas, que continuaram a crescer, muitos foram aqueles que viram neste processo de abertura, particularmente na retomada dos direitos políticos e das liberdades civis, uma lenta consolidação do Estado democrático de direito e das instituições políticas do país. Contudo, não apenas continua a predominar uma certa hipertrofia do Executivo, como as relações entre este e o Legislativo continuam a ser marcadas por demandas clientelistas, graças ao controle, em muitos estados, dos investimentos públicos regionais e da distribuição de cargos públicos por parte das elites. Este controle constitui-se em importante recurso de poder, particularmente naquela camada da população onde predomina uma fraca cidadania política. O Judiciário, por seu lado, continua marcado por ação bastante dúbia. Ainda que o acesso aos tribunais tenha aumentado para a população em geral, os custos das ações judiciais continuam a privar grande parte da população do acesso à justiça. Além disso, mesmo quando não tende a predominar a parcialidade na condução dos processos, a cultura jurídica predominante, não apenas corporativa e burocrática (Santos, 2007), como também profundamente conservadora, tende a tratar de forma desigual os mais ricos e os mais pobres. ${ }^{1}$

\footnotetext{
${ }^{1}$ Segundo dados do IBGE, em $198859 \%$ das pessoas entrevistadas que se envolveram em conflitos no país recorreram à justiça para resolvê-los. $41 \%$ preferiu não fazer nada ou tentou resolvê-los por conta própria.
} 
Por outro lado, muitos autores têm falado, com certo espanto, do crescimento da violência, tanto criminal quanto policial, no período pós-ditadura (Peralva, 2000; Pinheiro, 2000). Os estudos mais recentes têm destacado várias causas dessa "escalada" da violência (Santos, 2002). Primeiramente, o aumento das desigualdades sociais, graças ao desmonte do Estado social que se havia começado a construir com Vargas. Este desmonte, iniciado nos anos 1990, foi chamado cinicamente de "flexibilização do trabalho". Por "flexibilização" deve-se entender a maior liberdade dos empresários para demitir trabalhadores sem os ônus vigentes na legislação desde a instituição da $\mathrm{CLT}^{2}$ Ao mesmo tempo, tratava-se de diminuir o orçamento da previdência e de outros órgãos de atendimento público, sob o pretexto de combater o déficit público e a alta das taxas de juros. Na prática, isso tem significado o aumento do desemprego estrutural e da miséria de milhões de brasileiros. Segundo este modo de ver as coisas, a crise do Estado de bem-estar social redundou em uma crise do controle social informal que realizavam a família, a escola, a Igreja, entre outras instituições. Por outro lado, o sistema de justiça penal, não conseguindo substituir tais controles, levou a um aumento crescente da repressão policial. Esta crise do sistema penal tem se traduzido também em recorrente e crônico estado de impunidade. Outro efeito dessa crise seria a privatização do controle social, isto é, o crescimento, no campo como na cidade, das redes de segurança privada, bem como da "justiça paralela", exercida por justiceiros, matadores de aluguel e linchadores. $\mathrm{O}$ resultado de tudo isso seria um alargamento do recurso a formas violentas e ilegais de solução de conflitos, assim como uma certa "democratização da violência", já que potencialmente ninguém está a salvo de ser sua vítima (Santos, 2002; Barreira, 2008).

Ainda que todas essas causas tenham seu quinhão de verdade, elas, colocadas assim como estão, desestoricizam o problema da violência. Antes de tudo por que não mostram o papel histórico da violência nas relações de classe no Brasil, bem como a ampla aplicação de suas normas desiguais às diferentes classes sociais ao longo da formação social brasileira. Ora, como visto, as imensas desigualdades, a repressão policial aos mais pobres, a segurança privada, a justiça paralela, a correlação entre violência e condições de vida... não são apanágio da história recente do país, antes têm profundas raízes em seu passado colonial e escravocrata. Assim também não mostram a truculência policial que se exerce dentro da legalidade do Estado democrático, através da perseguição discriminatória das populações das periferias pobres e dos movimentos sociais e seus representantes, mas sobretudo que se exerce em violação estrita da lei,

${ }^{2}$ A Consolidação das Leis Trabalhistas (CLT), criada em 1 de maio de 1943, é a principal norma legislativa brasileira referente ao Direito do trabalho. 
nos casos de tortura e execuções sumárias que se tornaram regra nas grandes cidades, assim como dos massacres de trabalhadores rurais. Também não mostram que a impunidade que campeia nos casos de corrupção e de crimes de "colarinho branco", bem como nos assassinos de crimes da esfera privada (crimes passionais) e de crimes cometidos por policiais, ou o rigor que vigora nos casos de crimes cometidos pelas classes sociais de baixo poder aquisitivo, estão relacionados à forma desigual como o Estado trata as diferentes classes sociais no Brasil.

Pode-se dizer que este sentimento de desigualdade, que tem raízes ancestrais, não é apanágio das elites conservadoras do país, mas está mais ou menos diluído pela sociedade brasileira como um todo. Daí que os crimes cometidos por pessoas da classe média ou da elite - tais como corrupção, fraudes financeiras, evasão de impostos, exploração do trabalho infantil, trabalho escravo - não sejam considerados tão ameaçadores à ordem social quanto o são os crimes cometidos pelas classes de baixo poder aquisitivo. Daí que a solução violenta, legal ou ilegal, se aplique tão bem a uns e não a outros.

\section{Principais resultados e discussões da pesquisa}

A pesquisa de campo que serviu de base a este estudo durou cerca de um ano e foi realizada na região do Pontal do Paranapanema, extremo oeste do estado de São Paulo. Foram ao todo 25 entrevistas qualitativas diretas e abertas, com membros do MST, bem como fazendeiros da região, escolhidos em função das necessidades do estudo, ${ }^{3}$ somando quase 30 horas de gravações; 32 entrevistas indiretas, recolhidas em matérias de jornais, documentários e pesquisas feitas por outros pesquisadores; cerca de 320 notícias de jornais diários, entre os anos de 1990 e 2008 (os jornais consultados foram: O Imparcial, Oeste Notícias, Folha de S. Paulo e O Estado de S. Paulo); pesquisa de opinião estruturada com 200 entrevistados nas cidades de Presidente Prudente e Teodoro Sampaio; dados estatísticos sobre violência no campo, oriundos, sobretudo, da Comissão Pastoral da Terra (CPT) e do Núcleo de Estudos sobre Reforma Agrária (NERA); 10 processos jurídicos envolvendo sem-terra; dois documentários; 60 fotos, recolhidas de diversas formas (com pessoas entrevistadas, arquivos do MST e CPT, entre outros); cerca de 100 livros e artigos específicos sobre o tema. Em assim sendo, dado o número elevado de dados documentais, bem como o espaço reduzido deste artigo, os resultados apresentados a seguir representarão uma parte reduzida dos resultados mais amplos. Uma abordagem mais completa e complexa está

\footnotetext{
3 Trata-se, portanto, daquilo que se costuma chamar "amostra típica".
} 
contida em uma tese de Livre-Docência, apresentada em 2010 na Universidade de São Paulo. ${ }^{4}$

Ao olharmos para os dados da CPT, ${ }^{5}$ deparamo-nos com um paradoxo: frente ao alto número de ocupações no Pontal do Paranapanema, particularmente nos anos 1990, se comparada a outras regiões do Brasil como o Pará, é de se perguntar por que não houve mortes nesses anos tão difíceis? Aliás, essa parecia ser a grande perplexidade da época, de forma quase generalizada, como se pode perceber em várias notícias de jornais. A pesquisa detalhada desses casos, de 1990 a 2008, mostra que os dados existentes, sobretudo os da CPT, são enganosos, pois a violência no estado de São Paulo, ao menos no caso do Pontal, é bem maior do que se supõe. ${ }^{6}$ Mas é bem verdade também que ela não se compara, em termos de intensidade e de números, com regiões como o Pará ou mesmo o vizinho estado do Paraná, apesar de ter registrado um número de conflitos às vezes superior ao de regiões mais violentas. Em outras palavras, parece não haver relação direta entre conflito e violência, entre ocupação de terra e violência, como muitos estudiosos do tema, amparados, sobretudo, nos dados da CPT, fazem supor. Portanto, se a estrutura fundiária desigual explica o conflito, não é suficiente para explicar a violência. A violência tem outros condicionantes, outros elementos que buscamos com esta pesquisa apontar, mormente certa mentalidade arrogante dos fazendeiros, que acreditam poder fazer o que quiserem, por não serem cidadãos da mesma classe que os sem-terra ou estarem imunes ao rigor da lei. E na maior parte dos casos, amparados, sobretudo, em uma Justiça conservadora, a pesquisa mostrou que eles realmente podem.

E o que esta pesquisa permite constatar é que existem condicionantes estruturais, históricos, da violência no Brasil, que explicam inclusive esta arrogância dos fazendeiros. Situação esta mais ou menos generalizada em todo país. Mas existem também elementos específicos, próprios da história da região, que contribuíram para o não agravamento da situação de conflito, evitando assim violências extremadas. Ou seja, que explicam por que afinal

\footnotetext{
${ }^{4}$ A tese encontra-se disponível no banco de teses da USP, bem como o relatório científico de conclusão da pesquisa no site da Fundação de Amparo à Pesquisa do Estado de São Paulo (FAPESP). 5 A Comissão Pastoral da Terra é um órgão da Confederação Nacional dos Bispos do Brasil e foi criada em 1975 como resposta à grave situação dos trabalhadores rurais em todo o país. Trata-se de um dos mais importantes centros de documentação relativa à questão agrária e aos conflitos de terra.

${ }^{6}$ A CPT tem realizado ranques periódicos onde o estado de São Paulo sempre apareceu com um dos índices de violência mais baixos do país. Isto parece alimentar uma concepção largamente difundida sobre a "modernidade"de São Paulo, o estado mais desenvolvido do país. E é sintomático que os próprios sem-terra, como foi possível constatar em várias entrevistas, relacionem o fato de nunca ter havido mortes nos conflitos de terra de São Paulo com esta "superioridade cívica" do estado. Eles diziam: "Aqui não é o Pará...".
} 
não houve mortes no Pontal nestes momentos tão difíceis de sua história. O que se percebeu com a pesquisa é que a região tinha, ao menos na década de 1990, um alto potencial de violência, que não correspondia de todo ao alto nível de conflito existente, mas que não se deflagrou por uma série de razões. Este alto potencial de violência está inscrito inclusive na história do Pontal, que se buscou em alguma medida tratar em outros textos (Leonidio, 2009).

Segundo pôde averiguar esta pesquisa, os dois fatores que mais contribuíram para evitar desfechos trágicos no Pontal foram, por um lado, a situação das terras, em sua grande maioria devolutas, dando aos sem-terra a quase certeza de ganho de causa, e, por outro, a disposição dos sem-terra para o diálogo e a sua atitude legalista. O Estado, por sua vez, agiu de forma dúbia, o que elevou a temperatura em dados momentos. Do mesmo modo ambíguo agiu a polícia, o que se reflete na própria percepção dos sem-terra em relação a ela. Isso mostra que se os sem-terra mantinham claramente uma postura contrária à violência, o mesmo não se dava com os fazendeiros. Por seu lado, a opinião pública mantinha uma postura mais ambígua também. Estes são os principais resultados desta pesquisa, que buscaremos resumir a seguir.

A região conhecida hoje como Pontal do Paranapanema paulista começou a ser ocupada efetivamente após a promulgação da Lei de Terras de 1850, que proibia a aquisição de terras públicas através de qualquer outro meio que não fosse a compra. Todos aqueles que haviam adquirido suas terras antes da lei, deveriam regularizar sua posse, ou voltaria para os domínios do Estado. As inúmeras manobras realizadas para garantir a posse das vastas porções de terras ocupadas por fazendeiros-grileiros ${ }^{7}$ evidencia as dificuldades que a lei encontrou naquela que é considerada a última fronteira do estado de São Paulo. E as terras continuaram sendo griladas durante grande parte do século Xx. Depois de inúmeras contendas judiciais, em 1958, toda a região hoje conhecida como Mirante do Paranapanema (o chamado $11 .^{\circ}$ Perímetro) foi declarada devoluta.

Apesar disso, os fazendeiros-grileiros continuaram a ocupar estas terras e outras novas que iam adquirindo, sempre de forma fraudulenta. Daí resultaram vários conflitos entre grileiros e posseiros na região. Este contexto explica o surgimento, nesta época, no Pontal do Paranapanema, da figura histórica do "quebra-milho", capangas contratados por grandes grileiros com o fito de expulsar outros grileiros e posseiros que chegavam à região. Segundo informa Ferrari Leite (1998), não eram raros os cadáveres vistos

\footnotetext{
${ }^{7}$ Grileiros são falsificadores de títulos de propriedade da terra. O termo origina-se da técnica usada, que consiste em guardar os documentos em uma gaveta com grilos, tornando-os amarelados e roídos e, assim, com aparência antiga.
} 
boiando em águas dos rios do sertão sorocabano, vítimas dos conflitos de terra que se intensificavam na região. Uma vez por outra, jornais regionais como $A$ Voz do Povo, Folha Sorocabana, O Imparcial noticiavam conflitos violentos na região, como os que ocorreram entre 5 e 26 de março de 1939, dos quais resultaram vários mortos e feridos.

Mas apesar de casos de violência como estes, havia um cenário social mais ou menos pacificado na região, com os pobres do campo colocados em seu lugar subalterno na estrutura produtiva, como arrendatários, trabalhadores temporários, assalariados ou capangas das grandes fazendas. Mas tudo isso começou a mudar com a chegada do MST à região. Então a imprensa começou a falar da "violência no Pontal".

A primeira ocupação de terras no Pontal se deu em 1990, na fazenda Nova Pontal, no município de Rosana. Apesar de ter apresentado momentos bastante difíceis durante sua desocupação, bastando lembrar o fato de se ter feito dois oficiais reféns e a Polícia Militar chegar ao local com sacos plásticos para recolher os mortos, esta não foi das ocupações mais violentas ocorridas na região. Munidos então da descoberta da situação jurídica do 11. ${ }^{\circ}$ Perímetro, os sem-terra ${ }^{8}$ partiram para uma estratégia nova, ocupar as áreas com problemas de titulação. A primeira delas foi a fazenda São Bento, ocupada pela primeira vez em março de 1991, mas que foi ocupada várias outras vezes depois. Foram ao todo 23 liminares de reintegração de posse e uma tentativa de sequestro das terras por parte do estado de São Paulo (Folha de S. Paulo, 30. 05. 91 e 03. 06. 91). Apesar também de contar com vários momentos de tensão, não foi esta a ocupação que resultou em situações de violência extrema.

Depois da São Bento, vieram várias outras ocupações na região de Mirante do Paranapanema, todas envolvendo situações muito similares, entre as quais, cumpre destacar: Santa Clara, em novembro de 1991; Flor Roxa, Washington Luiz e Santa Cruz, em julho de 1992; Estrela Dalva, em novembro de 1993; Haroldina e Arco Íris, em abril de 1995; Santa Rita e Santa Irene, em janeiro de 1996. A Estrela Dalva foi a campeã de ocupações, com quase uma centena de casos e a Santa Rita foi de todas a mais violenta, com vários atentados a tiros contra os acampamentos, localizados fora da propriedade, ${ }^{9}$ um dos quais

\footnotetext{
${ }^{8}$ Trata-se aqui do Movimento dos Trabalhadores Rurais Sem-Terra (MST), que durante quase toda a década de 1990 protagonizou sozinho a história das ocupações no Pontal.

9 Entre as estratégias do MST na região estava a ocupação sem acampamentos nas fazendas. Isto é, os sem-terra entravam na área, trabalhavam a terra para plantio de alimentos durante o dia e à noite iam para seus acampamentos, localizados às margens das rodovias. Com isso, evitavam os desgastes das liminares de reintegração de posse, além da possibilidade do conflito violento. Mas como veremos, e como foi o caso da Santa Rita, bem como de inúmeras outras fazendas, isso nem sempre foi possível, pois os fazendeiros atacavam os sem-terra mesmo fora dos limites de suas propriedades.
} 
resultou em ferimentos a bala na repórter da emissora de TV brasileira SBT, Mônica Teixeira, que realizava à época um documentário sobre os conflitos de terra no Pontal do Paranapanema.

No final de 1996, os sem-terra mudaram a estratégia e passaram a ocupar fazendas que não estavam de acordo com o artigo constitucional, que versa sobre a função social da terra. Depois de vários anos e de várias ocupações, com a São Domingos, em outubro de 1996, é a primeira vez que os sem-terra ocupam terras fora do $11 .{ }^{\circ}$ Perímetro. ${ }^{10}$ Não é por mero acaso que de todos os conflitos, este foi o mais violento, resultando em oito feridos a bala, sendo dois deles com grande gravidade. Uma das pessoas feridas, a Miriam, confessou em entrevista: “... foi a primeira vez que os fazendeiros atiraram mesmo pra matar...”. Apesar de ter sido rearticulada na sede da fazenda Santa Rita, o quartel general da União Democrática Ruralista (UDR) ${ }^{11}$ foi a fazenda São Domingos, que se tornou também para os fazendeiros uma espécie de símbolo de "resistência" às ocupações. Estes e outros casos similares mostram, portanto, que a questão da titularidade das terras foi um fator importante de abrandamento das tensões, evitando que o desfecho dos conflitos pudesse ter redundado em mortes. Mas mostra também, e de forma ainda mais importante, que o direito de propriedade no Brasil funciona como uma prerrogativa legal para atitudes ilegais por parte daqueles que se julgam acima da lei.

Mas nem todos os fazendeiros estavam dispostos a negociar com o Estado. Para a UDR, negociar significava reconhecer a não legitimidade de suas terras, apesar da obviedade dos casos. ${ }^{12}$ Então, sobretudo nestas situações, o mero problema de titulação não era suficiente para acalmar os ânimos. Foi preciso muito jogo de cintura e certa disposição para o diálogo por parte dos sem-terra. Desde o início, fica claro que a disposição dos sem-terra é a de quem não quer o conflito, ou melhor, de quem quer resolvê-lo de forma não violenta. A aposta dos sem-terra sempre foi, ao que tudo indica, em uma solução pacífica para os casos. Foram vários os momentos em que os sem-terra ameaçaram resistir à desocupação, mesmo com as tropas de choque armadas até os dentes, mas ao fim acabaram saindo pacificamente. E isso se

\footnotetext{
${ }^{10}$ A região do Pontal do Paranapanema, extremo oeste do estado de São Paulo, foi dividida em 13 perímetros, para fins de regularização de sua situação fundiária. O $11 .^{\circ}$ Perímetro era onde se concentrava a maior parte das terras devolutas e por isso onde os sem-terra costumavam ocupar fazendas.

${ }^{11}$ A UDR foi uma entidade patronal rural criada nos anos 1980, no contexto da Nova Constituição Brasileira, e pretendia ser o braço forte dos ruralistas contra a reforma agrária em todo o Brasil. Além de sua base política, pois contava com o apoio de vários deputados no Congresso Nacional, ela organizou várias milícias armadas no campo.

${ }_{12}$ Alguns fazendeiros que entrevistei disseram categoricamente tratar-se de uma invenção dos sem-terra e da mídia o problema das terras devolutas no Pontal.
} 
traduz claramente no fato de nunca ter havido um confronto violento entre sem-terra e polícia no Pontal..$^{13}$ Ademais, a própria postura legalista do MST, acatando invariavelmente os mandados de reintegração de posse decretados pela Justiça, contribuiu muito para o abrandamento das tensões e para se evitar um derramamento de sangue.

É de se notar que a postura legalista, de respeito às decisões judiciais e ao cumprimento dos mandatos por parte da Polícia são sempre ressaltados como uma espécie de valor moral positivo para os sem-terra. Nesse sentido, foram muito reveladoras também as respostas à pergunta sobre se eles consideravam a ocupação um ato violento. A maioria não achava o ato em si violento. Invariavelmente, nas mais de vinte entrevistas realizadas, foram dois tipos de argumentos mobilizados, um de fundo moral, outro legal, ambos em estreita associação. Os argumentos morais destacavam, por um lado, a necessidade, a carência das pessoas, bem como a esperança de uma vida melhor. Por outro, o fato de se tratar de pessoas humildes, que estão movidas por um sonho, o sonho da terra. Assim, por corresponder a uma necessidade vital das pessoas, sendo portanto justo, o ato não era violento.

Por seu lado, os argumentos legais foram os mais mobilizados pelos entrevistados. Uma parte, como o Seu Nilo, justificava a ocupação dizendo tratar-se de uma ocupação da terra e não da sede, onde o proprietário reside com sua família. Outros diziam estar ocupando terra devoluta e improdutiva, e que os fazendeiros nunca deixavam de ser indenizados por isso. Outros ainda enfatizavam tratar-se da ocupação de algo desocupado ou subocupado, e não de invasão. Portanto, por não ser ilegal, não era violento.

Houve também respostas ambíguas, que reiteram essa mesma visão moral/ /legal que perpassa todos os discursos. Já na primeira ocupação, da fazenda Nova Pontal, em 1990, o problema estava colocado. Na época, os sem-terra fizeram dois oficiais de justiça reféns, a fim de negociarem a desocupação. O próprio José Rainha Jr., importante liderança regional dos sem-terra à época, declarou depois na imprensa tratar-se de ato isolado, ${ }^{14}$ que não refletia a mentalidade e nem o modus operandi do MST. Depois foi o caso da fazenda Estrela Dalva, onde houve muita matança de boi. Pouco depois, o mesmo Rainha voltou a desculpar-se publicamente, embora justificando que o povo estava

\footnotetext{
${ }^{13}$ A única exceção se deu durante uma operação de desbloqueio da ponte Maurício Joppert da Silva, que liga São Paulo a Mato Grosso do Sul, em Presidente Epitácio, quando uma sem-terra e três policiais ficaram feridos. Mas é importante observar que este caso envolveu sem-terra ligados ao movimento Brasileiros Unidos Querendo Terra, que conta com estratégias diferentes do MST (O Estado de S. Paulo, 17.09.97).

${ }_{14}$ Ponto de vista esse também defendido por várias pessoas que acompanharam a história do movimento no Pontal, como os entrevistados Thomaz, Jefferson, Carlos, Dom José, entre outros.
} 
com fome e que o governo não havia enviado as cestas básicas prometidas em acordo anterior. A Mirian, em entrevista, justificou a atitude através do argumento da falta de maturidade política do movimento em seus primórdios (Entrevista, 27.11.07).

Nas demais entrevistas, foram vários os sem-terra que disseram ser contra essas práticas, como o Cidão: “... desde que os dirigente faça as coisas consciente, para que não haja destruição, não haja nada... aquilo que a via campesina fez no Paraná... para mim aquilo é uma atitude hostil... eu acho que aquilo está errado..." (Entrevista, 02.04.08). Outros até chegaram a repetir argumentos da opinião pública mais conservadora, como o militante Guilhermão: "Não é porque tem um baderneiro no meio que você vai condenar todo o povo... baderneiro sempre tem..." (Entrevista, 27.11.07). No mesmo sentido, Rosângela Aparecida chegou a fazer um apelo emocionado à opinião pública: "O Movimento Sem Terra é uma coisa muito bonita! Onde tem muita humanidade! E queria pedir que, quando eles vissem assim um acontecimento negativo num assentamento ou acampamento, não julgassem todos os outros. Porque nós temos cinco dedos nas mãos, mas nenhum é igual ao outro" (Entrevista, 13.10.07).

A postura dos fazendeiros também sempre foi muito clara em relação aos conflitos: para eles a violência não só era um recurso legítimo como até necessário. ${ }^{15} \mathrm{E}$ ao contrário dos sem-terra, que quando tinham alguma postura que resvalava para a violência faziam questão de tentar justificá-la, os fazendeiros assumiam publicamente a agressividade. Neste sentido, é preciso deixar bem marcado que essa violência explícita foi muito marcante nos anos 1990, quando os fazendeiros acreditavam que ela tinha certa função a cumprir. Nos anos 2000, sobretudo a partir de 2003, com o governo Lula, ela passou a ser mais velada, por uma série de razões que depois mencionaremos.

Até 1992, os conflitos violentos eram poucos e não sistemáticos. No fim de 1992, particularmente após o assentamento das famílias de sem-terra na área da antiga fazenda São Bento, os fazendeiros passaram a usar sistematicamente o recurso bélico como forma de combate às ocupações. Em agosto de 1992, o então presidente da UDR, Roosevelt Roque dos Santos, assumiu publicamente estar orientando proprietários de terras do Pontal a utilizarem armas para impedir ocupações. Segundo ele, "o uso da força é legal quando se trata de defesa da propriedade" (O Imparcial, 22.08.92). A partir de 1994, a UDR começou a trazer pistoleiros de Mato Grosso para formar milícias armadas na região, grande parte deles ex-policiais. Em junho deste ano, a Secretaria da Justiça do

${ }^{15}$ Um dado muito sintomático deste estado de espírito dos fazendeiros foi a imensa dificuldade encontrada para entrevistá-los. A maioria se recusou, às vezes de forma grosseira, a conceder entrevistas. 
Estado reconheceu que o problema era grave na região e emitiu nota pública condenando a movimentação dos fazendeiros. Segundo o secretário, Antônio Corrêa Meyer, isso poderia ampliar o conflito e a violência na região: "A UDR deve procurar os meios legais para se defender [...] Deve recorrer à Polícia e evitar o confronto direto" (Folha de S. Paulo, 30. 06. 94).

Durante algum tempo a UDR ficou inativa, mas no fim de 1996 ela voltou às atividades. Em setembro deste ano, particularmente em função das ocupações fora do 11 . $^{\circ}$ Perímetro, cerca de 250 fazendeiros do Pontal decidiram rearticular a entidade (O Estado de S. Paulo, 14.09.96). Por essa mesma época, uma ala dos fazendeiros considerada pelo próprio MST como sendo mais "moderada", ligada ao Sindicato Rural de Presidente Prudente, dirigiu-se aos sem-terra a fim de alertá-los para a gravidade da situação. Joel Amaro Mascarenhas, vice-presidente da entidade afirmou "o clima é propício ao enfrentamento". "Eles estão armados e prontos para enfrentar as ocupações de terras". Bechara Saab, integrante de uma comissão de negociação sobre o conflito agrário no Pontal, reitera o recado: "Eu vim pedir aos sem-terra um pouco de calma e que evitem novas invasões, pois o clima não é nada bom [...] Estamos a um passo de um confronto, se uma das partes não ceder" (O Estado de S. Paulo, 14.09.96). O resultado das ameaças não demorou a aparecer. Em janeiro de 1997, a fazenda Santa Rita, momentaneamente sede das operações da nova UDR, ${ }^{16}$ foi desocupada por conta dos próprios fazendeiros. A Polícia foi chamada e o que se presenciou foi no mínimo inusitado, conforme depoimento do capitão de polícia Renato Ryukiti Sanomya:

Fui ao local, por volta das 9 h, quando a situação era tensa. Tentei dialogar, mas minha surpresa foi grande quando 12 ou 13 seguranças se afastaram e tomaram posição de tiro [...] Fui obrigado a dar uma rajada de metralhadora para mostrar que nosso armamento é pesado. (Folha de S. Paulo, 13.01.97)

Mas de todos os conflitos violentos ocorridos, ${ }^{17}$ o mais exemplar, no sentido de mostrar claramente a mentalidade dos fazendeiros, a naturalidade com que assumem as práticas violentas como mecanismo de resolução de conflitos, se deu na fazenda Concórdia, no município de Tarabaí, pouco depois do episódio anteriormente narrado. Nesta data, cerca de 200 sem-terra tentaram ocupar a fazenda e foram expulsos a tiros por cerca de 20 capangas. Durante

\footnotetext{
${ }^{16}$ Nessa época havia muita movimentação na fazenda, com entra e sai de ônibus carregados de capangas, bem como de aviões vindos de Mato Grosso, alguns deles trazendo armas, como depois ficaria provado em investigação policial.

17 Aqui estamos tomando como exemplo apenas alguns deles. Uma análise mais completa foi apresentada na tese de Livre-Docência anteriormente citada.
} 
cerca de 10 minutos, foram disparados mais de 200 tiros, segundo cálculos do delegado de polícia Adalberto Gonini Jr. Os sem-terra tiveram de rolar por um barranco de 15 metros, abandonando todos os seus pertences na área, para não serem mortos. O fazendeiro Guilherme Coimbra Prata, dono da fazenda e vice-presidente da UDR no Pontal, comandou a ação. Ele admitiu que atirou para matar: "Só não acertei porque sou muito ruim de tiro, mas agora vou treinar e da próxima vez não erro" (O Estado de S. Paulo, 28.01.97). O recado, com todo o despudor possível, estava dado.

Entre aqueles considerados mais "moderados", segundo o próprio MST, ligados ao Sindicato Rural, há diferença de tom e linguagem, mas o pesquisador Antônio Thomaz Jr., em entrevista, enfatizou que eles também querem ver os sem-terra mortos. Nilton Teixeira, criador de gado há 40 anos na região, em entrevista cedida na sede do Sindicato, em Presidente Prudente, chegou mesmo a discordar desta distinção em relação aos colegas da UDR. Acredita ainda que a polícia deveria agir como se fosse segurança privada dos fazendeiros, impedindo as ocupações: “[...] Então ele (o fazendeiro) é obrigado muitas vezes a tomar uma decisão que talvez não seja a mais certa, porque quem teria que fazer isso (atirar nos sem-terra) seria o poder constituído, que deveria dar segurança para essas propriedades" (Entrevista, 20.04.09).

Perguntado sobre a disposição para o diálogo e os acordos para resolver os conflitos de terra por parte do Sindicato, mas não por parte da UDR, o fazendeiro exaltou-se: “... hoje o poder judiciário está aí para mostrar o contrário, haja visto o número de ações favoráveis aos proprietários rurais, dizendo que essas terras não são devolutas coisa nenhuma..." (Entrevista, 20.04.09). Esta certeza jurídica tem inclusive mudado a forma dos conflitos agrários na região. Desde 2003 que não se ouve mais falar de um incidente envolvendo capangas armados no Pontal. Os testemunhos dos sem-terra foram unânimes em afirmar que a violência agora está mais velada, com outra roupagem. Ela teria dado lugar a uma atuação bastante regular e marcante do Judiciário. Não que antes o judiciário não tivesse importância. Todos os sem-terra entrevistados também foram unânimes em traçar uma clara distinção entre a atuação da Polícia e do Judiciário. Enquanto a Polícia, em particular a Polícia local, estaria aberta a negociações, ${ }^{18}$ o Judiciário era extremamente intransigente;

\footnotetext{
${ }^{18}$ Todos afirmaram que a Polícia chegava a negociar prazos de desocupação: se o Judiciário mandava desocupar, a Polícia ia ao local e negociava com os sem-terra um prazo maior de permanência, dando tempo para que eles arranjassem outro local para ficarem. Isto é, aquilo que em muitos lugares era papel da mediação de conflitos, ganhar tempo, segundo as palavras do próprio entrevistado do ITESP, no Pontal, muitas vezes, era resolvido diretamente com a Polícia. O próprio secretário de Justiça da época, 1991, chegou a dizer na imprensa que "a polícia vem atrapalhando a Justiça no caso das invasões" (O Imparcial, 21.11.91).
} 
além de ter perseguido severamente os sem-terra e de criminalizá-los reiteradamente. ${ }^{19}$ Acontece que nos anos 2000 o protagonismo do Judiciário parece ter sido bem maior, o que fez com que os fazendeiros e suas milícias quase saíssem de cena. ${ }^{20} \mathrm{E}$ essa atuação do Judiciário está sem dúvida relacionada às mudanças que vêm ocorrendo no Pontal desde então, com a entrada de grandes empresas e bancos à frente das usinas produtoras de açúcar e álcool (Thomaz Jr., 2009).

A julgar pelas notícias de jornais, era de se esperar que a opinião pública em geral endossasse esta visão, que tende a legitimar a violência praticada nos conflitos de terra no país, conforme hipótese inicialmente levantada no projeto. Contudo, a pesquisa revelou uma opinião pública bastante ambígua. A opinião conservadora, criminalizadora do MST, se tem respaldo nos grandes centros urbanos, que tomam conhecimento do movimento por meio da própria mídia, não o tem nas pequenas cidades, mormente naquelas onde a presença do MST é marcante.

Pesquisa realizada pelo IBOPE em 2006 revelou que quase um em cada três entrevistados vê o governo federal como principal responsável pelos conflitos no campo. Tecnicamente empatados em segundo lugar, vêm o MST, com $16 \%$, e os fazendeiros, com $15 \%$. Segundo $53 \%$ dos entrevistados, a polícia deveria ser usada para "retirar integrantes do MST" de propriedades rurais. Frente aos resultados da pesquisa, tanto o vice-presidente da Confederação Nacional da Agricultura, que encomendou a pesquisa, Rodolfo Tavares, como o diretor jurídico da UDR foram unânimes em concluir que a maioria da população desaprova os "métodos violentos do MST".

Pesquisa realizada em 2008 pelo mesmo IBOPE, mas desta vez encomendada pela Vale do Rio Doce, obteve resultados muito semelhantes. Para $45 \%$ dos entrevistados, a palavra que melhor descreve o MST é violência. O mais interessante desta pesquisa é o seu universo amostral: 2100 pessoas ao todo, sendo 1204 nas metrópoles (São Paulo, Rio de Janeiro, Belo Horizonte, Curitiba, Porto Alegre, Recife, Distrito Federal, Salvador e Fortaleza) e o restante nas seguintes cidades: Vitória, São Luiz, Belém e Marabá (PA). $97 \%$ dos entrevistados afirmou conhecer "bem" o MST, sendo que $90 \%$ afirmou conhecê-lo pela televisão e o restante pelos jornais e demais meios

\footnotetext{
${ }_{19}$ Esta pesquisa mostrou uma necessidade de aprofundar os estudos sobre a atuação tanto da Polícia quanto do Judiciário na região do Pontal do Paranapanema. Alguns documentos já foram recolhidos neste sentido, como os processos contra sem-terra, bem como alguns contatos com juízes que tiveram atuação marcante nos anos 1990 também já foram feitos.

${ }^{20}$ Isto é, todos os sem-terra também foram unânimes em afirmar que os fazendeiros continuam armados. A cabine blindada da fazenda Santa Rita continua de pé, como símbolo da disposição para a guerra.
} 
de comunicação. Para 45\% dos entrevistados das regiões metropolitanas, a cobertura dos meios de comunicação é neutra, mas $35 \%$ acham que os veículos tendem a ser favoráveis aos sem-terra.

Minha pesquisa, realizada em duas cidades do Pontal, Teodoro Sampaio e Presidente Prudente, num universo amostral de 200 pessoas, teve resultados bastante diferentes. $87 \%$ dos entrevistados não acham a violência necessária para resolver os conflitos de terra. $36 \%$ acham a ação do MST violenta, mas justa; $9 \%$ violenta e injusta; $47 \%$ pacífica e justa. $11 \%$ acham a ação dos fazendeiros violenta, mas justa; $78 \%$ violenta e injusta; $5 \%$ pacífica e justa. Quanto aos maiores responsáveis pela violência no campo, a pesquisa confirmou resultados obtidos pelo IBOPE: 0\% MST; 4\% os fazendeiros; $64 \%$ o estado e $32 \%$ a polícia. Resultado bastante diferente também foi aquele obtido quando o assunto era como eles agiriam caso estivessem no lugar dos fazendeiros. Enquanto na pesquisa do IBOPE a população se mostrou dividida, na pesquisa do interior paulista a esmagadora maioria, $73 \%$, afirmava recorrer à Justiça. A maioria também desaprova o uso da força policial, diferentemente da pesquisa do IBOPE, que também mostra certa ambiguidade.

O que fica claro então é que tanto a ambiguidade quanto a desaprovação do MST é muito mais marcante nas capitais do que no interior, que vive de perto a realidade das ocupações e dos conflitos violentos. Fica claro, portanto, que o mosaico da cultura política brasileira tem traços bastante diferenciados, conforme se trata de capitais ou de interior. Mas essa cultura política das capitais, de origem profundamente conservadora, mas fortemente marcante das classes médias, está intimamente atrelada ao valor da cordialidade de Sérgio Buarque de Holanda, como cultura da relação de intimidade para resolução de conflitos, revelando uma população ressentida e pouco afeita às lutas sociais. Isso mostra, por último, que quem tem uma visão complacente com a violência e a injustiça é a imprensa conservadora, os fazendeiros, o governo, etc., mas não os movimentos sociais e os pobres.

\section{Conclusões principais}

Este trabalho buscou relacionar as condições históricas que tornam aceitáveis e até justificáveis variadas formas de violência rural no Brasil contemporâneo. A primeira e mais importante condição foram os quase quatro séculos de escravidão, que banalizou o prazer de matar e torturar, bem como fez que parecesse necessário e vantajoso comportar-se de forma violenta. Mas mais que tudo, fez que parecesse natural matar ou torturar aqueles que se apresentavam como um corpo estranho à nação: os escravos naqueles tempos coloniais e imperiais e os pobres e despossuídos na nova República, a partir de 1889 . 
Ora, a partir do século XIX, gradativamente, foi-se constituindo um Estado nacional de tipo laico, amplamente inspirado no modelo liberal, então em vigor em vários países capitalistas. Este modelo encontrou, como visto, vários problemas na estrutura escravista e colonial herdada. Entre estes problemas cumpre destacar as dificuldades dos membros da nação em se reconhecerem publicamente na lei, mormente no que se refere ao sentimento de igualdade jurídica formal. De modo que apesar de o Estado criar um aparelho jurídico-policial normatizador das relações, Estados paralelos continuaram em vigor ao longo dos anos, de variadas formas: potentados locais, coronelismo, capangagem, milícias rurais, tráfico de drogas, entre outros. Este poder paralelo sempre criou suas próprias normas, em geral voltadas para favorecer os membros do grupo e punir os excluídos. Em sendo assim, não acompanhou a evolução do Estado racional uma moral repressora dos instintos mais agressivos e o autocontrole da violência. Isso explica porque as agressões físicas e até os homicídios nunca regrediram a uma espécie de segundo plano nas situações de conflito no Brasil, apesar dos avanços do "Estado moderno".

Este sentimento de desigualdade, bastante naturalizado na sociedade brasileira, parece ser o pano de fundo de certa inoperância das regras do Estado democrático, quando as vítimas são aqueles excluídos do pacto social. Neste sentido, se a regra tem sido a de uma ampla intolerância que serve aos interesses dos que se julgam ameaçados na hierarquia social, o outro lado da moeda é uma ampla tolerância da violência, uma vez que ela não parece representar um risco generalizado às pessoas, apesar de nos meios urbanos ela ser bem mais "difusa". Assim, é bem verdade que nos meios urbanos há um sentimento generalizado de insegurança que ronda as pessoas, mas não há como comparar este sentimento com aqueles dos moradores das periferias pobres, constantemente ameaçadas por policiais e encapuzados. Nos meios rurais, por seu lado, ele parece ser um sentimento quase exclusivo de posseiros e sem-terras. Apesar de toda exposição midiática, a população das pequenas cidades, mormente aquelas onde o peso do rural é grande, não veem os conflitos de terra, e em particular a ação dos sem-terra, como uma ameaça a sua segurança. Isto foi o que mostraram as pesquisas sobre o Pontal do Paranapanema realizadas.

Aqui é muito importante deixar bem claro que o processo histórico e generalizado de criminalização dos movimentos sociais e suas lideranças no Brasil tem um sentido muito preciso. Ora, como criminoso no Brasil não tem direitos garantidos, justifica-se por isso qualquer arbitrariedade contra ele cometida. Daí porque, como dito, o Estado e a opinião pública fazem constantes mea culpa quando há evidências de os assassinatos envolverem 
pessoas inocentes. Esta cultura política mostrou todo seu esplendor durante os anos de ditadura militar. Com isso, reforçou-se junto à opinião pública uma mentalidade altamente favorável ao emprego de métodos violentos pela polícia, à instauração da pena de morte, ou ao recurso a métodos de justiça ilegal, como os linchamentos. Até hoje, essa mentalidade permanece, quando se trata de violência criminal, onde muita gente pensa que para reduzir o número de crimes é necessário intensificar a repressão, inclusive com o emprego direto das Forças Armadas com funções de polícia.

Nas quase duas décadas de história de conflitos de terra no Pontal do Paranapanema analisadas, foram vários os resultados de um tal estado de coisas: vários pedidos de prisão expedidos contra sem-terras e suas lideranças; várias prisões efetuadas; intenso clima de perseguição e tortura psicológica; torturas físicas; arbitrariedades policiais; rápidas e abundantes liminares de reintegração de posse; reiteradas negações de habeas corpus aos sem-terra e concessão dos mesmos aos fazendeiros; lento tramitar dos processos envolvendo terras devolutas na região; várias arbitrariedades na condução dos processos envolvendo sem-terras, além da violência direta dos fazendeiros sobre se terras.

Tais ações violentas, como visto, não foram lineares, mas tiveram seus altos e baixos, havendo momentos de forte protagonismo do Estado e outros em que quem ocupava este papel eram os próprios fazendeiros, com suas milícias armadas. No que se refere à violência institucional, percebe-se, não só pelos depoimentos, mas pelos demais dados analisados, que a ação da Justiça foi muito mais efetiva que a da própria polícia, de forma a garantir o direito de propriedade, aumentando a exclusão e a marginalização crescente dos pobres do campo. Assim, o que se percebe claramente é que contra os sem-terra o cumprimento da lei tem sido, em todos esses casos, bastante rigoroso. Ao contrário, quando seus direitos são violados, muitas vezes pelo próprio Estado, a Justiça tem sido inoperante. Não é de se estranhar, portanto, que apesar da postura legalista do MST, como visto, predomine entre os sem- terra uma descrença generalizada em relação às soluções institucionais para o problema dos conflitos de terra.

De fato, o que se pode observar com a história de luta dos sem-terra no Pontal, é que as soluções judiciais têm sido conseguidas por meio de ações extrajudiciais, que são as ocupações de terra. E estas mesmas ações têm sido criminalizadas e perseguidas pelo próprio direito estatal. E isso está fortemente relacionado à cultura jurídica no Brasil. Trata-se de uma cultura que vêo "povo pobre ativo”, que luta por seus direitos, sob constante suspeição. Ademais, a própria formação dos magistrados brasileiros, assente no positivismo jurídico, torna muito difícil o aceite de uma concepção social da propriedade. 
Obviamente, esta cultura política tem se constituído em poderoso alimento para as atitudes arbitrárias e truculentas dos próprios ruralistas. Em suma, dadas as dificuldades históricas em adentrar o mundo da lei e dele fazer uso, bem como a pressão violenta exercida pelos fazendeiros, por meios legais ou não, e todo clima desfavorável criado pela imprensa, tem havido um forte refluxo dos movimentos sociais no Pontal, desde o início dos anos 2000. Apesar de a situação das terras devolutas ainda permanecer tal como no fim dos anos 1980, antes da chegada dos sem-terra.

\section{Referências bibliográficas}

Almeida, Angela Mendes de (1999), Família e modernidade: o pensamento jurídico brasileiro no século XIX. São Paulo: Porto Calendário.

Barreira, César (2008), Cotidiano despedaçado. Cenas de uma violência difusa. Campinas: Pontes.

Elias, Norbert (1999), La civilisation des moeurs. Paris: Pocket.

Freyre, Gilberto (1987), Casa grande e senzala. Rio de Janeiro: José Olympio.

Holanda, Sérgio Buarque de (1995), Raízes do Brasil. São Paulo: Companhia das Letras.

Leite, José Ferrari (1998), A ocupação do Pontal do Paranapanema. São Paulo: Hucitec. Leonidio, Adalmir (2009), "Violências fundadoras", Ambiente e Sociedade, 12(1), 37-47.

Méndez, Luis H. (1999), "Violencia simbólica en el territorio maquilador fronterizo", El cotidiano, 19(125), 7-20.

Peralva, Angelina (2000), Violência e democracia. O paradoxo brasileiro. Rio de Janeiro: Paz e Terra.

Pinheiro, Paulo S. (2000), "O passado não está morto: nem passado é ainda", in Paulo S. Pinheiro (org.), Democracia, violência e injustiça. O não-Estado de direito na América Latina. Rio de Janeiro: Paz e Terra.

Prado Jr., Caio (1995), Formação do Brasil contemporâneo. São Paulo: Brasiliense.

Queirós, Maria I. P. (1982), "O coronelismo numa interpretação sociológica", in Boris Fausto (org.), História Geral da Civilização Brasileira - vol. 8. São Paulo: Difel, 153-190.

Santos, José Vicente Tavares dos (1999), "Novos processos sociais globais e violência", São Paulo em Perspectiva, 13( 3), 19-37.

Santos, José Vicente Tavares dos (2002), "Violências, América Latina: a disseminação de formas de violência e os estudos sobre conflitualidade", Sociologias, 8, 45-62.

Santos, José Vicente Tavares dos (2004), "Violências e dilemas do controle social nas sociedades da modernidade tardia”, São Paulo em Perspectiva, 18 (1), 3-12.

Santos, Boaventura de Sousa (2007), Para uma revolução democrática da justiça. São Paulo: Cortez. 
106 | Adalmir Leonidio

Thomaz Jr., Antônio (2009), Dinâmica geográfica do trabalho no século XXI. Tese de Livre-

-Docência. Presidente Prudente/SP: Unesp.

Wieviorka, Michel (1997), “O novo paradigma da violência”, Tempo Social, 9(1), 33-48.

\section{Jornais}

O Estado de S. Paulo, 14.09.1996; 28.01.1997; 17.09.1997

Folha de S. Paulo, 30.05.1991; 03.06.1991; 30.06.1994

O Imparcial, 21.11.1991; 22.08.1992

\section{Entrevistas}

Carlos Almeida, Técnico do ITESP, 02.12.2007

“Cidão", Militante do MST, 02.04.2008

Claudemir Cano, Militante do MST, 03.09.2008

Cledson, Militante do MST, 04.09.2008

“Guilhermão", Militante do MST, 27.11.2007

Márcio Barreto, Militante do MST, 03.09.2008

Miriam, 27.11.2007

Nilton Teixeira, Fazendeiro, 20.04.2009

Rosângela Aparecida, Militante do MST, 13.10.2007

"Seu Nilo", Militante, 27.11.2007

Thomaz Jr., Professor Unesp, 15.07.2009

\section{Dados quantitativos}

Comissão Pastoral da Terra (CPT), www.cptnac.com.br, 1998-2010

Núcleo de Estudos da Reforma Agrária (NERA), www.fct.unesp.br/nera, 2006-2010

IBOPE, www.ibope.com.br, 2006/2008 